\title{
Ocena przełomów złączy spawanych po próbie łamania
}

\section{Assessment of weld joints fractures after fracture}

\section{Streszczenie}

Omówiono próbę łamania złączy spawanych prowadzoną zgodnie z wymaganiami PN-EN 1320:1999. Przedstawiono wymagania dotyczące przygotowania próbek do próby łamania oraz jej realizację. Dokonano oceny przełomów złączy spawanych po próbie łamania.

$\mathrm{Na}$ zdjęciach przełomów zaznaczono niezgodności spawalnicze ujawnione w próbie łamania. Dla każdego przełomu przeprowadzono ocenę wraz z opisaniem niezgodności spawalniczych oraz zakwalifikowaniem ich do odpowiednich poziomów jakości zgodnie z PN-EN ISO 5817:2009.

\section{Abstract}

The breaking welded joints performed according to the requirements of PN-EN 1320:1999 was presented in the book. Moreover, all the requirements related to the preparation of samples to the trial of breaking welded joints and its realization were introduced. An assessment of welded joints fractures after the breaking trial was discussed.

The photographs of fractures show welding defects revealed during the breaking trial. For each fracture and assessment with a description of welding defects is given. Moreover, all the defects are classified into the relevant quality levels in accordance with the PN-EN ISO 5817:2009.

\section{Wstęp}

Egzaminowanie spawaczy stali i stopów niklu przeprowadza się wg EN 287-1:2011 [1]. Jednym z najczęściej stosowanych sposobów oceny złączy spawanych jest ocena przełomu po próbie łamania. Próba łamania ma wiele zalet:

- można ją przeprowadzić w warunkach warsztatowych, a do jej realizacji wystarczają proste narzędzia lub maszyny (młot, dźwignia, prasa balansowa lub hydrauliczna),

- można ją wykonać szybko,

- charakteryzuje się niskim kosztem realizacji.

Ważną cechą próby łamania jest to, że w przypadku spoin czołowych umożliwia ujawnienie przyklejeń międzyściegowych, których nie można ujawnić w badaniu metodą np. RT. Usytuowanie tej niezgodności nie powoduje zmiany natężenia promieniowania, a tym samym zaistnienia warunku fizycznego badań RT.

Dr hab. inż. Jacek Słania, prof. IS, mgr inż. Krzysztof Staniszewski, mgr inż. Katarzyna Hyc - Instytut Spawalnictwa, Gliwice.

Analiza literatury wskazuje na brak materiałów poglądowych z zakresu oceny złączy spawanych po próbie łamania, dostępnych dla inżynierów spawalników, kontrolerów jakości i kandydatów na egzaminatorów spawaczy. Obecnie wiedza ta przekazywana jest najczęściej między oceniającymi. Niniejsza publikacja stanowi pewnego rodzaju uzupełnienie tej wiedzy, a zakres opracowania obejmuje przełomy złączy po próbie łamania spoin wykonanych metodami:

- ręcznego spawania elektrodą otuloną (111),

- spawania łukowego drutem elektrodowym litym w osłonie gazu aktywnego (135),

- spawania łukowego elektrodą wolframową w osłonie gazu obojętnego $\mathrm{z}$ dodatkiem drutu/pręta litego (141).

Przedstawiono ocenę wraz z opisaniem niezgodności spawalniczych oraz zakwalifikowaniem ich do odpowiednich poziomów jakości zgodnie z PN-EN ISO 5817:2009 [2] po wykonaniu próby łamania. Próbę łamania złączy przeprowadzono z wykorzystaniem prasy hydraulicznej o sile nacisku $60 \mathrm{t}$. Analiza przełomu ujawniła liczne niezgodności spawalnicze $z$ grup 2, 3 i 4 wg PN-EN ISO 6520-1:2009 [3]. 


\section{Próba łamania wg PN-EN 1320}

PN-EN 1320:1999 [4] zawiera sposoby prowadzenia próby łamania oraz wielkości próbek stosowanych w tym badaniu. Jako cel próby łamania norma podaje uzyskanie przełomu próbki tak, aby można było wykryć wewnętrzne niezgodności spawalnicze, takie jak: pęcherze, pęknięcia, przyklejenia, braki przetopu oraz wtrącenia. Norma przewiduje badanie wszystkich materiałów złączy spawanych uzyskanych dowolną metodą o grubości $\geq 2 \mathrm{~mm}$ [4].

W PN-EN 1320 przywołano następujące definicje:

- długość badana $\left(\mathrm{L}_{\mathrm{f}}\right)$ : długość próbki zmierzona między ewentualnymi bocznymi karbami wzdłuż osi spoiny (rys. 6);

- łączna długość badana $\left(\Sigma \mathrm{L}_{\mathrm{f}}\right)$ : łączna długość powierzchni przełomu wszystkich próbek złącza próbnego pomiędzy bocznymi karbami próbek, zmierzona wzdłuż osi spoiny (rys. 6);

- grubość badana $\left(\mathrm{a}_{\mathrm{f}}\right)$ : grubość powierzchni przełomu każdej próbki (rys. 7 i 8);

- powierzchnia badana $\left(A_{f}\right)$ : iloczyn długości i grubości badanej każdej próbki;

- łączna powierzchnia badana $\left(\Sigma \mathrm{A}_{\mathrm{f}}\right)$ : Suma wszystkich badanych powierzchni.

Norma przewiduje, że w celu oceny powierzchni przełomu powinien on przebiegać przez spoinę. Przełom może powstać na skutek działania sił rozciągających lub zginających zarówno statycznych, jak i dynamicznych. Dodatkowo, w celu zainicjowania przełomu można zmienić wymiary karbu i temperaturę badania. Jeżeli nie ustalono inaczej, badanie należy wykonać w temperaturze pokojowej $(23 \pm 5)^{\circ} \mathrm{C}$.

Określenia i symbole wykorzystywane w PN-EN 1320:1999 podane są w tablicy I. Zazwyczaj wystarcza

Tablica I. Określenia i symbole

Table I. Denominations and symbols

\begin{tabular}{|l|c|c|}
\hline \multicolumn{1}{|c|}{ Określenia } & Symbol & Jednostka \\
\hline Spoina czołowa & $\mathrm{BW}$ & - \\
Spoina pachwinowa & $\mathrm{FW}$ & - \\
\hline Próbka i złącze próbne & & \\
- długość badana & $\mathrm{L}_{\mathrm{f}}$ & $\mathrm{mm}$ \\
- grubość badana & $\mathrm{a}_{\mathrm{f}}$ & $\mathrm{mm}$ \\
- powierzchnia badana & $\mathrm{A}_{\mathrm{f}}$ & $\mathrm{mm}^{2}$ \\
- powierzchnia niezgodności & $\mathrm{A}_{\mathrm{i}}$ & $\mathrm{mm}^{2}$ \\
\hline Karb boczny & $\mathrm{S}^{2}$ & \\
- czworokątny (q) & $\mathrm{S}_{\mathrm{q}}$ & - \\
- okragły (r) & $\mathrm{S}_{\mathrm{r}}$ & \\
- trójkątny (s) & $\mathrm{S}_{\mathrm{s}}$ & \\
\hline Karb wzdłużny & & \\
od strony lica & $\mathrm{F}$ & \\
- czworokątny (q) & $\mathrm{F}_{\mathrm{q}}$ & \\
- okrągły $(\mathrm{r})$ & $\mathrm{F}_{\mathrm{r}}$ & \\
- trójkątny (s) & $\mathrm{F}_{\mathrm{s}}$ & - \\
od strony grani & $\mathrm{R}$ & \\
- czworokątny (q) & $\mathrm{R}_{\mathrm{q}}$ & \\
- okrągły $(\mathrm{r})$ & $\mathrm{R}_{\mathrm{r}}$ & \\
- trójkątny (s) & $\mathrm{R}_{\mathrm{S}}$ & \\
\hline
\end{tabular}

podanie podstawowych określeń, jednak w szczególnych przypadkach mogą być wymagane dodatkowe dane dotyczące rodzaju karbów i metody badania.

W normie podano przykłady oznaczeń.

\section{Przykład 1}

Próbka ze złącza ze spoiną pachwinową, o długości badanej $50 \mathrm{~mm}$ i grubości badanej $15 \mathrm{~mm}$ :

- bez wymagań dot. karbów i sposobu badania,

Podstawowe oznaczenie: FW / $\mathrm{L}_{\mathrm{f}} \times \mathrm{a}_{\mathrm{f}}(\mathrm{np}$. FW / $50 \times 15)$

- $z$ dodatkowymi wymaganiami (karby wzdłużne od strony lica czworokątne i sposób badania).

Pełne oznaczenie: $\mathrm{FW} / \mathrm{L}_{\mathrm{f}} \times \mathrm{a}_{\mathrm{f}} / \mathrm{F}_{\mathrm{q}}$ (rys. 9)

(np. FW / $\left.50 \times 15 / F_{q}\right)$

\section{Przykład 2}

Próbka ze złącza doczołowego, o długości badanej $50 \mathrm{~mm}$ i grubości badanej $15 \mathrm{~mm}$ :

- bez wymagań dot. karbów i sposobu badania

Podstawowe oznaczenie: BW / $\mathrm{L}_{\mathrm{f}} \times \mathrm{a}_{\mathrm{f}}$

(np. BW / 50 x 15)

- $z$ dodatkowymi wymaganiami (karby boczne okrągłe i sposób badania)

Petne oznaczenie: $\mathrm{BW} / \mathrm{L}_{\mathrm{f}} \times \mathrm{a}_{\mathrm{f}} / \mathrm{S}_{\mathrm{r}}$ (rys. 7)

(np. BW/ $40 \times 10 / \mathrm{S}_{\mathrm{r}}$ )

Wymiary złącza próbnego przedstawiono na rysunkach $1 \div 4$. Wymiary te mogą być zmienione, jeżeli wymaga tego norma wyrobu lub jeśli takie jest ustalenie pomiędzy stronami kontraktu. Powinna istnieć możliwość wykonania ze złącza próbnego wystarczającej liczby próbek, tak aby spełnić wymagania dotyczące łącznej długości badania $\left(\Sigma L_{f}\right)$ oraz łącznej powierzchni badania $\left(\Sigma A_{\mathrm{f}}\right)$.

Jeżeli wykonywana jest próba łamania, złącze próbne powinno być cięte na co najmniej cztery próbki do badania i złamane - jedną z możliwości przedstawiono na rysunku 5.

Ustalenia, co do długości badania $\left(\mathrm{L}_{\mathrm{f}}\right)$, powierzchni badania $\left(A_{f}\right)$ oraz liczby próbek powinny znajdować się w normie wyrobu lub w porozumieniu między stronami kontraktu. Próbki powinny być w przybliżeniu jednakowej długości, powinny być wycięte ze złącza blach poprzecznie do spoiny, a oś spoiny czołowej powinna się znajdować $w$ ich środku. Jeżeli norma lub porozumienie pomiędzy stronami kontraktu nie przewiduje inaczej, ze złącza próbnego powinny być pobrane minimum dwie próbki. Każde złącze próbne powinno być tak oznakowane, aby możliwe było dokładne określenie jego położenia w wyrobie lub w spoinie, z której zostało pobrane. Każda próbka, która pobrana została ze złącza próbnego, powinna być oznakowana. Próbki powinny być pobrane metodą, która pozwala na uniknięcie niekorzystnych wpływów mechanicznych lub cieplnych. Jeżeli nie są wymagane informacje o końcach spoiny (np. niezgodności spawalnicze początku i końca spoiny), to norma zaleca usunięcie $25 \mathrm{~mm}$ materiału z obu końców spoin próbnych.

Próbki stalowe mogą być wycięte metodą mechaniczną lub cięcia termicznego. Próbki wykonane 


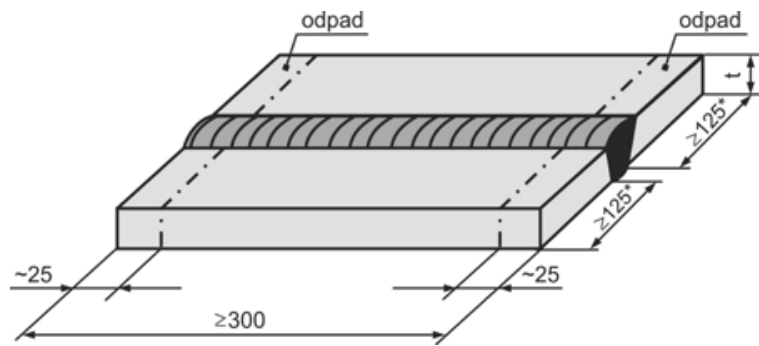

Rys. 1. Złącze próbne blach ze spoiną czołową (wymiary w $\mathrm{mm}$ ); *) $\geq 150 \mathrm{~mm}$ dla materiałów o wysokiej przewodności cieplnej (np. aluminium i miedź); $\mathrm{t}$ - grubość złącza próbnego

Fig. 1. Test piece for butt weld in plates (dimensions in $\mathrm{mm}$ ); $\left.{ }^{*}\right) \geq 150$ $\mathrm{mm}$ for materials of high thermal conductivity (e.g. aluminium and copper); $\mathrm{t}$ - the thickness of the test joint

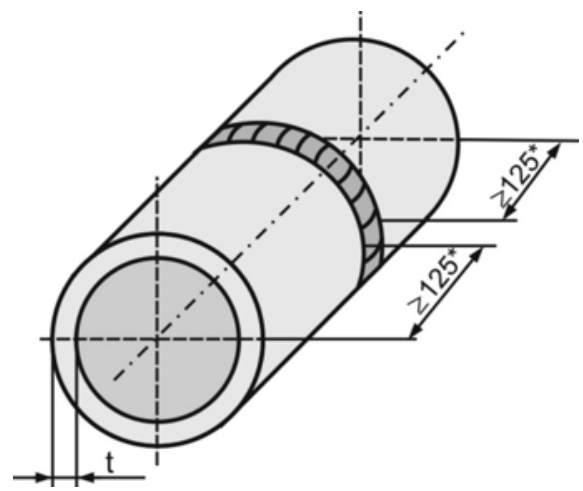

Rys. 2. Złącze próbne rur ze spoiną czołową (wymiary w $\mathrm{mm}$ ) $\left.{ }^{*}\right) \geq 150 \mathrm{~mm}$ dla materiałów o wysokiej przewodności cieplnej (np. aluminium i miedź); $\mathrm{t}$ - grubość złącza próbnego

Fig. 2. Test piece for butt weld in pipes (dimensions in $\mathrm{mm}$ ); $\left.{ }^{*}\right) \geq 150$ $\mathrm{mm}$ for materials of high thermal conductivity (e.g. aluminium and copper); $\mathrm{t}$ - the thickness of the test joint

z innych metali mogą być wykonywane tylko przez cięcie termiczne.

W celu ułatwienia łamania spoin blach lub rur można stosować jeden lub więcej spośród niżej wymienionych sposobów:

- usunięcie nadlewów spoin,

- nacięcie karbów na obu brzegach spoiny (boczne karby),

- nacięcie karbów w nadlewie spoin (wzdłużne karby).

W zależności od ciągliwości spoiny mogą być wykonywane karby czworokątne, okrągłe lub trójkąt-

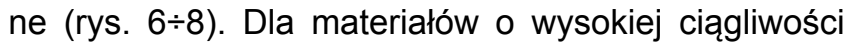
(np. aluminium i miedź) norma zaleca wykonywanie karbów trójkątnych. Głębokość stosowanych karbów powinna być na tyle duża, aby uzyskać przełom w spoinie.

Jeżeli nie określono tego w normach wyrobu lub w porozumieniu pomiędzy stronami kontraktu, głębokość karbów powinna być następująca:

- dla karbów bocznych: długość badana $L_{f}$ powinna być równa lub większa niż $70 \%$ początkowej szerokości próbki $w$ (rys. 7) lub całkowita długość badana $\Sigma L_{\mathrm{f}}$ powinna być równa lub większa niż $60 \%$ długości złącza próbnego;

- dla karbów wzdłużnych: grubość badana a, powinna być równa lub większa niż $80 \%$ początkowej grubości t próbki (rys. 8, 9).

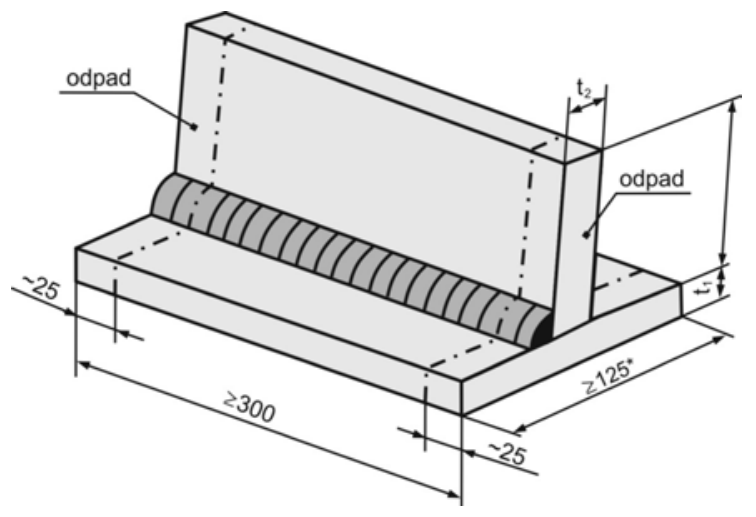

Rys. 3. Złącze próbne blach ze spoiną pachwinową (wymiary w mm); *) $\geq 150 \mathrm{~mm}$ dla materiałów o wysokiej przewodności cieplnej (np. aluminium i miedź); $t_{1}, t_{2}$ - grubości złącza próbnego

Fig. 3. Test piece for fillet weld on plates (dimensions in $\mathrm{mm}$ ); $\left.{ }^{*}\right) \geq 150 \mathrm{~mm}$ for materials of high thermal conductivity (e.g. aluminium and copper); $t_{1}, t_{2}$ - the thicknesses of test joint

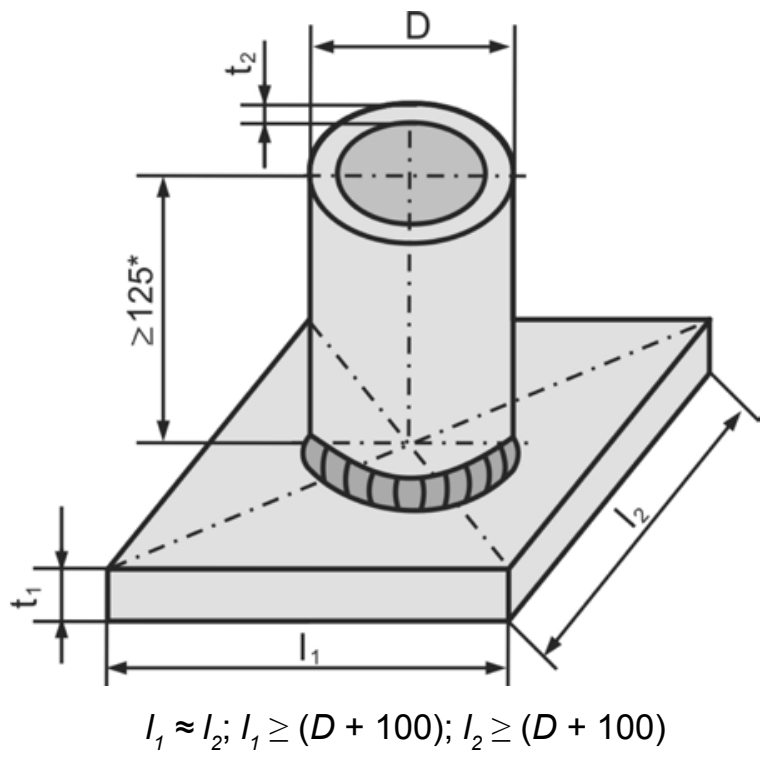

Rys. 4. Złącze próbne rura - blacha ze spoiną pachwinową (wymiary w mm); *) $\geq 150 \mathrm{~mm}$ dla materiałów o wysokiej przewodności cieplnej (np. aluminium i miedź); $t_{1}, t_{2}-$ grubości złącza próbnego; $\mathrm{I}_{1}, \mathrm{I}_{2}$ - długości złącza próbnego

Fig. 4. Test piece for fillet pipe-plate weld (dimensions in $\mathrm{mm}$ ) $\left.{ }^{*}\right) \geq 150 \mathrm{~mm}$ for materials of high thermal conductivity (e.g. aluminium and copper); $t_{1}, t_{2}$ are the thicknesses of test joint; $l_{1}, I_{2}-$ the lengths of test joint



Rys. 5. Przygotowanie złącza i realizacja próby łamania spoiny pachwinowej na rurze

Fig. 5. Joint preparation and fracture test performance 
$r$
5

Rys. 6. Kształty karbów Fig. 6. Notch profiles

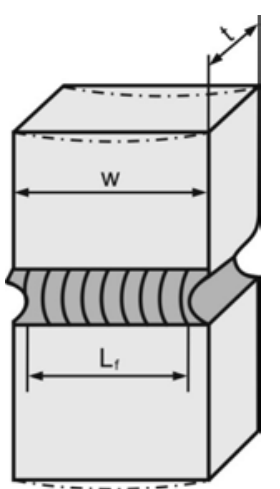

Rys. 7. Karby boczne (linia ciągła - blachy; linia punktowo-kreskowa - rury) Fig. 7. Side notches (full line for plates, dot-and-dash line for pipes)
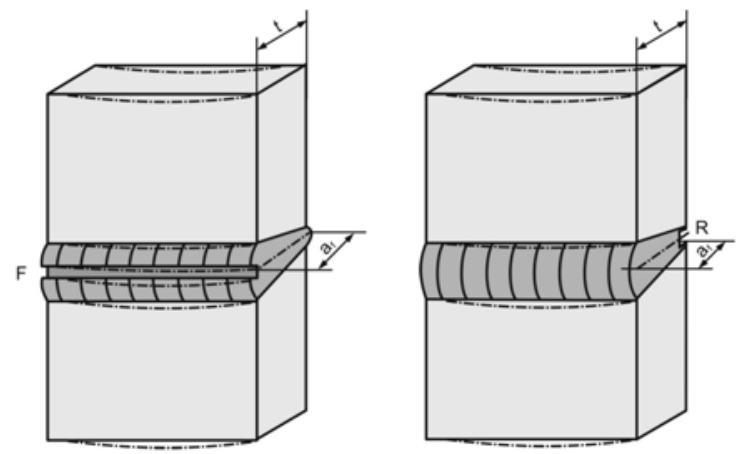

Rys. 8. Karby wzdłużne w spoinach czołowych (linia ciągła - blachy; linia punktowo-kreskowa - rury): a) karb wzdłużny w licu spoiny, b) karb wzdłużny w grani spoiny

Fig. 8. Longitudinal notches in butt welds (full line for plates, dot-anddash line for pipes): a) face notch, b) root notch



Rys. 9. Karb wzdłużny w spoinie pachwinowej

Fig. 9. Longitudinal notch in fillet weld

\section{Metody realizacji próby łamania}

\section{Spoiny czołowe}

Próbę łamania można przeprowadzić:

- dynamicznie, np. uderzając młotkiem (rys. 10a $\div$ c)

- stosując nacisk na próbkę umocowaną w imadle, maszynie do zginania lub prasie warsztatowej (rys. 10d $\div$ f);

- wykorzystując naprężenia rozciągające (rys. 10g).

Zachowanie niewielkiego odstępu pomiędzy karbami a szczękami może być korzystne w przypadku badania metali ciągliwych (rys. 10c). W celu ułatwienia zainicjowania powstania przełomu dla niektórych metali pomocne może być badanie w obniżonej temperaturze.
W przypadku łamania cienkich złączy spawanych może być niezbędne obustronne zginanie, w zależności od ciągliwości metalu. Nacisk na próbkę w zaciskach powinien być wywierany możliwie blisko karbów. Jeżeli próbka nie zostanie złamana, to norma zaleca wyprostowanie jej do pierwotnego kształtu i ponowne zginanie. Zamiast zginania norma proponuje rozciąganie (rys. 10g). Norma nie zaleca stosowania uderzeń młotkiem dla cienkich materiałów.

W przypadku badania grubych materiałów norma dopuszcza uderzanie młotkiem. Jeżeli do łamania takich materiałów zostanie wykorzystana maszyna do zginania, to średnicę trzpienia gnącego należy tak dobrać, aby nastąpiło złamanie bez konieczności stosowania obustronnego zginania. Stosowana siła zginająca może zostać przyłożona prostopadle lub poprzecznie do spoiny, odpowiednio do rysunków 10c $\div$ f. Wymagana grubość do badań aluminium wynosi $\mathrm{t} \geq 8 \mathrm{~mm}$.

\section{Spoiny pachwinowe}

Metody, z których można korzystać przy łamaniu spoin pachwinowych, są podobne do stosowanych przy spoinach czołowych z tym wyjątkiem, że nie można stosować rozciągania. Przykłady przedstawiono na rysunku 11.

Dla materiałów ciągliwych, jak np. stal austenityczna, aluminium, miedź, nikiel i ich stopy można sto- a)

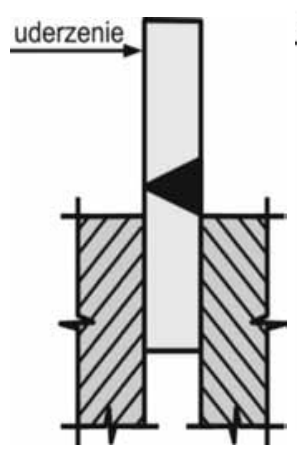

d)

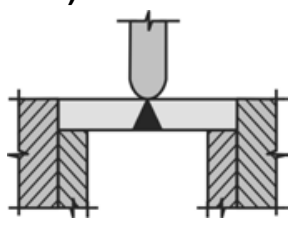

g)

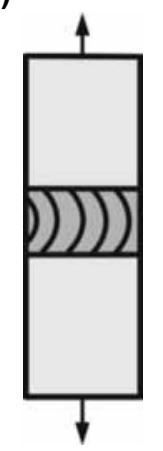

b)

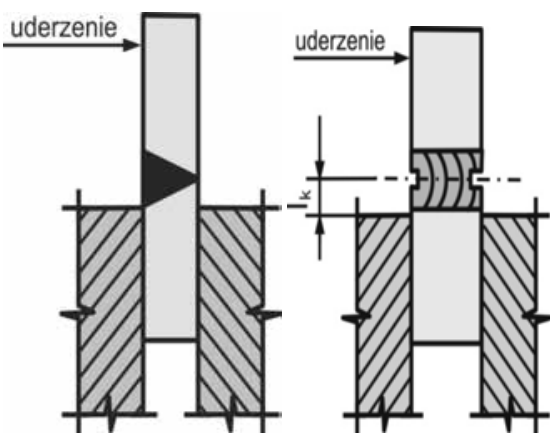

e)

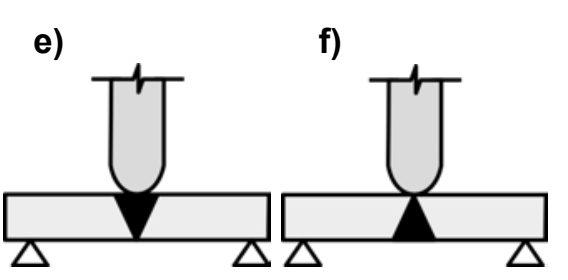

c)
Rys. 10. Przykłady sposobów łamania spoin

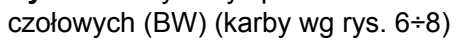

Fig. 10. Examples of fracture test methods for butt welds (BW) (notches in acc. with Fig. 6 to 8$)$ 


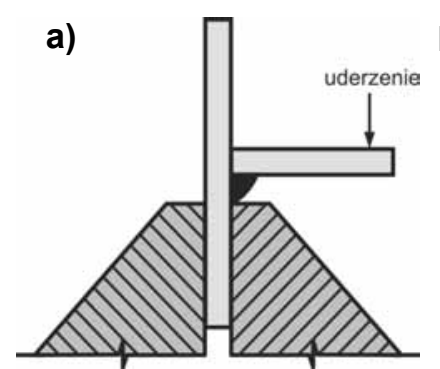

b) kierunek nacisku

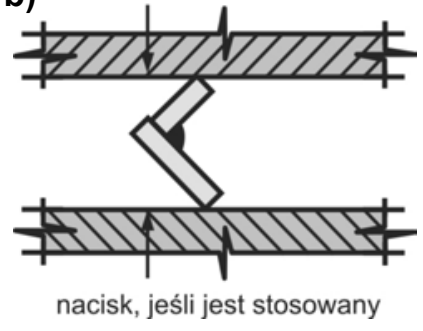

c) kierunek nacisku

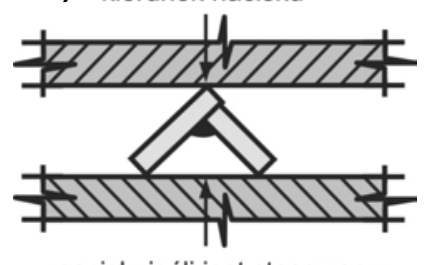

nacisk, jeśli jest stosowany

Rys. 11. Łamanie spoin pachwi-

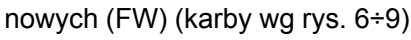
Fig. 11. Fracture test for fillet welds (FW) (notches in acc. with Fig. 6 to 9$)$

sować ograniczenie grubości próbek i grubości spoin pachwinowych, zwiększenie szerokości karbów, zmniejszenie promienia karbu oraz efektu uderzenia i siły uderzeniowej młotka, jeżeli wymagany jest przełom w spoinie. Dla spoin ciągliwych można stosować oziębianie spoin. PN-EN 1320:1999 daje dość szeroką możliwość wyboru sposobu łamania próbek, tak aby osoba prowadząca badania mogła wybrać środek jej zdaniem najbardziej odpowiedni i dostępny w danych warunkach warsztatowych. Jednym z najprostszych, dostępnym prawie w każdych warunkach sposobem jest dynamiczne uderzenie próbki np. za pomocą młotka. Możliwe jest także wykorzystanie mniej lub bardziej złożonych urządzeń mechanicznych.

\section{Wyniki badań}

PN-EN 1320:1999 nakazuje powierzchnie przełomu poddać badaniom wizualnym zgodnie z PN-EN ISO 17637:2011 [8]. W badaniach można zastosować lupę o powiększeniu do 5 razy w celu jednoznacznego wykrycia oraz rozpoznania niezgodności spawalniczych.

Norma nakazuje dokładne opisanie powierzchni przełomu i ujęcie w protokole obecności i położenia ewentualnych niezgodności spawalniczych. Poziom wymagań norma ustala na podstawie PN-EN ISO 5817:2009 lub PN-EN ISO 10042:2008 [9]. Poziom jakości nie jest narzucony przez normę i powinien być ustalony na podstawie normy wyrobu lub porozumienia pomiędzy stronami kontraktu.

\section{Protokół badań}

Protokół badań powinien zawierać:

- powołanie się na PN-EN 1320:1999,

- oznaczenie próbki,

- określenie próbki wg tablicy I;

- opis rodzaju, położenia i wielkości wszystkich niedopuszczalnych niezgodności spawalniczych w powiązaniu z odpowiednim poziomem wymagań.

\section{Wprowadzenie do oceny przełomów}

PN-EN ISO 6520-1:2009 definiuje niezgodność spawalniczą jako nieciągłość w spoinie lub odchylenie od zamierzonej geometrii. Przy dokonywaniu oceny wizualnej zgodnie z PN-EN ISO 5817:2009 dla oceniającego ważnym aspektem badania jest opis jakości spoiny na podstawie wybranych niezgodności spawalniczych. $\mathrm{Na}$ przypisanie odpowiedniego poziomu jakości do złącza spawanego składają się odpowiednie kryteria zdefiniowane dla poszczególnych niezgodności. Przy określonym poziomie jakości kryteria różnią się w zależności od rodzaju niezgodności spawalniczej.

Jednym z ważnych kryteriów jest niezgodność spawalnicza krótka, gdy spoina ma długość $100 \mathrm{~mm}$ lub więcej. Niezgodności spawalnicze należy traktować jako niezgodności krótkie, jeżeli na odcinku $100 \mathrm{~mm}$ obejmującym największą liczbę niezgodności ich całkowita długość nie jest większa niż $25 \mathrm{~mm}$. Natomiast, gdy spoina nie jest dłuższa niż $100 \mathrm{~mm}$, niezgodności spawalnicze należy traktować jako niezgodności krótkie, jeśli ich długość nie jest większa niż $25 \%$ długości spoiny. W przypadku kiedy niezgodność spełnia definicję niezgodności spawalniczej krótkiej, należy sprawdzić kolejne kryteria akceptacji dla danego poziomu jakości. Jeśli definicja niezgodności spawalniczej krótkiej nie jest spełniona, to oceniający bez rozważania kolejnych kryteriów dla danego poziomu jakości przechodzi do poziomu jakości niższego. Podczas próby łamania złączy teowych ze spoiną pachwiną, przy rozpatrywaniu niezgodności spawalniczej typu 402 zgodnie z PN-EN ISO 5817:2009 dopuszczony jest brak przetopu w poziomie jakości $D$ po spełnieniu odpowiednich kryteriów. Jednakże kryteria postawione w normie są niezmiernie trudne do weryfikacji dla tego rodzaju złączy. Dlatego też $w$ tym przypadku należy powołać się na EN 287-1:2011 dotyczącą egzaminowania spawaczy. Norma ta wskazuje, że pojawienie się tego typu niezgodności spawalniczej jest niedopuszczalne na żadnym z poziomów jakości. Jedynym dopuszczalnym poziomem EN 287-1:2011 jest wystąpienie niezgodności spawalniczych tylko na poziomie jakości B z wyłączeniem nadmiernego nadlewu oraz wycieku, które są dopuszczone tylko na poziomie jakości C. Poniżej zostały umieszczone zdjęcia wykonane po próbie łamania złączy teowych i złączy doczołowych wraz z opisem niezgodności występujących w przełomie oraz ocena tych niezgodności wg PN-EN ISO 5817:2009 [10] 


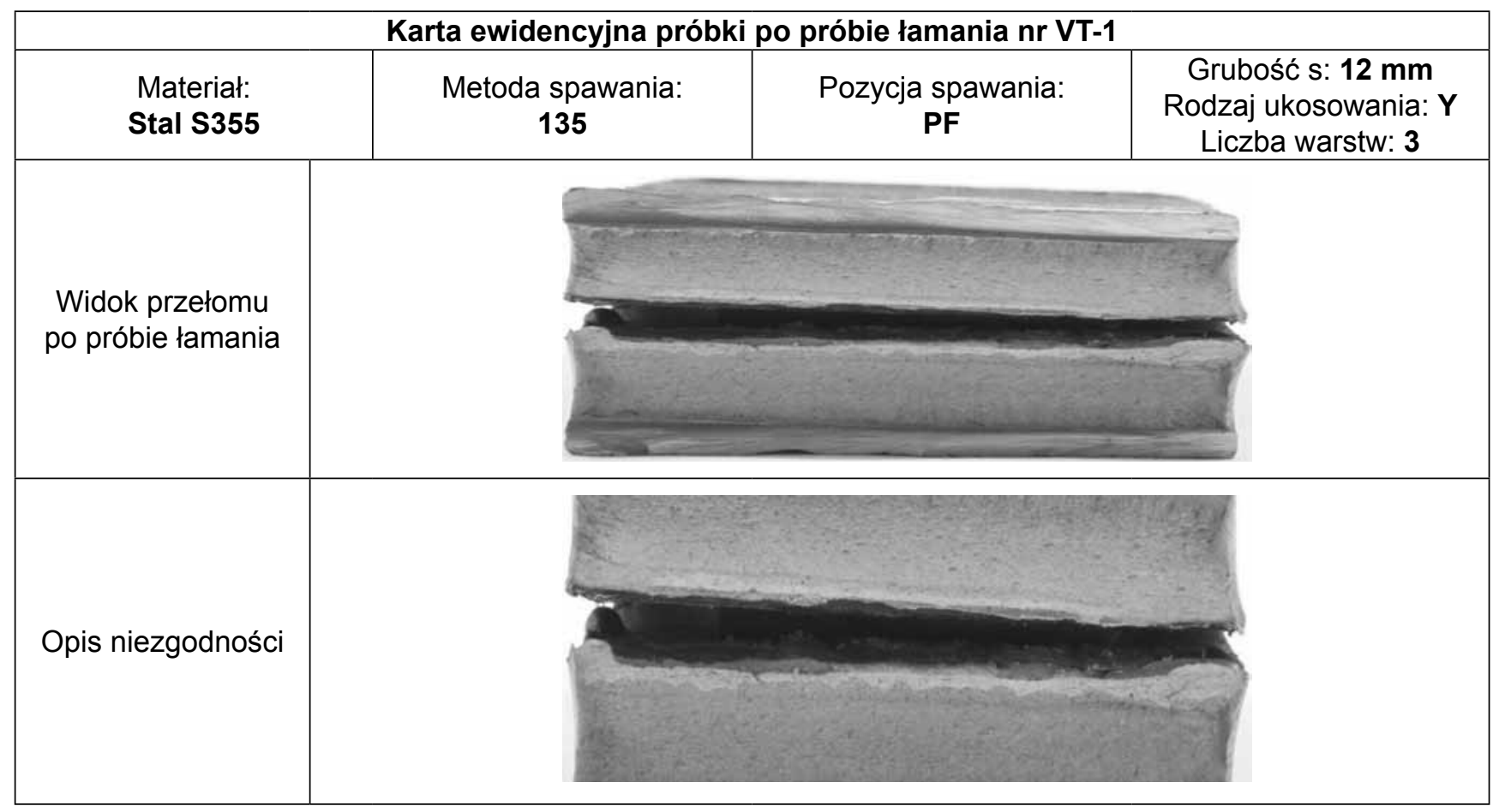

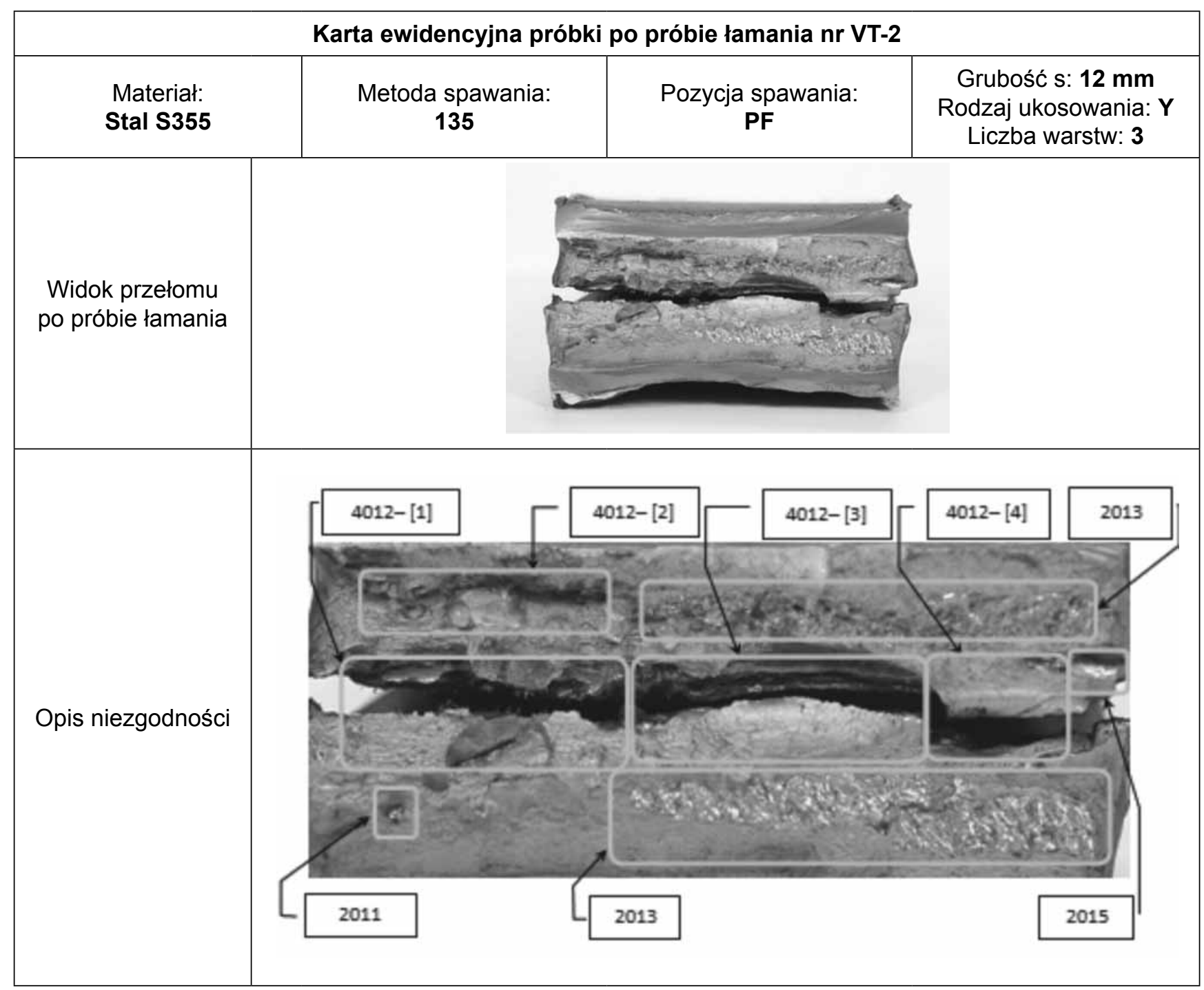


Opis niezgodności do karty ewidencyjnej próbki po próbie łamania VT-2

\begin{tabular}{|c|c|c|c|c|c|c|c|}
\hline \multirow{2}{*}{ Lp. } & \multirow{2}{*}{ Niezgodność } & \multirow{2}{*}{$\begin{array}{l}\text { Symbol } \\
\text { wg ISO } \\
6520-1\end{array}$} & \multicolumn{3}{|c|}{ Poziom jakości wg PN-EN ISO 5817} & \multirow{2}{*}{$\begin{array}{c}\text { Wielkość } \\
\text { niezgodności }\end{array}$} & \multirow{2}{*}{ Poziom } \\
\hline & & & D & C & $\mathrm{B}$ & & \\
\hline 1. & $\begin{array}{l}\text { Przyklejenie } \\
\text { międzywarstwowe }\end{array}$ & $4012[1]$ & $\begin{array}{l}\text { Dopuszcza się } \\
\text { niezgodności spa- } \\
\text { walnicze krótkie: } \\
\mathrm{h} \leq 0,4 \mathrm{~s} \\
\text { ale max } 4 \mathrm{~mm}\end{array}$ & Nie dopuszcza się & Nie dopuszcza się & $\mathrm{h}=6,5 \mathrm{~mm}$ & NSD \\
\hline 2. & $\begin{array}{l}\text { Przyklejenie } \\
\text { międzywarstwowe }\end{array}$ & $4012[2]$ & $\begin{array}{l}\text { Dopuszcza się } \\
\text { niezgodności spa- } \\
\text { walnicze krótkie: } \\
\mathrm{h} \leq 0,4 \mathrm{~s} \\
\text { ale } \max 4 \mathrm{~mm}\end{array}$ & Nie dopuszcza się & Nie dopuszcza się & $\mathrm{h}=7,7 \mathrm{~mm}$ & NSD \\
\hline 3. & $\begin{array}{l}\text { Przyklejenie } \\
\text { międzywarstwowe }\end{array}$ & $4012[3]$ & $\begin{array}{l}\text { Dopuszcza się } \\
\text { niezgodności spa- } \\
\text { walnicze krótkie: } \\
\mathrm{h} \leq 0,4 \mathrm{~s} \\
\text { ale max } 4 \mathrm{~mm}\end{array}$ & Nie dopuszcza się & Nie dopuszcza się & $\mathrm{h}=15,3 \mathrm{~mm}$ & NSD \\
\hline 4. & $\begin{array}{l}\text { Przyklejenie } \\
\text { międzywarstwowe }\end{array}$ & $4012[4]$ & $\begin{array}{l}\text { Dopuszcza się } \\
\text { niezgodności spa- } \\
\text { walnicze krótkie: } \\
\mathrm{h} \leq 0,4 \mathrm{~s} \\
\text { ale max } 4 \mathrm{~mm}\end{array}$ & Nie dopuszcza się & Nie dopuszcza się & $\mathrm{h}=8,5 \mathrm{~mm}$ & NSD \\
\hline 6. & Pęcherz podłużny & 2015 & $\begin{array}{l}\mathrm{h} \leq 0,4 \mathrm{~s}, \max 4 \mathrm{~mm} \\
\mathrm{I} \leq \mathrm{s}, \max 75 \mathrm{~mm}\end{array}$ & $\begin{array}{l}\mathrm{h} \leq 0,3 \mathrm{~s}, \max 3 \mathrm{~mm} \\
\mathrm{l} \leq \mathrm{s}, \max 50 \mathrm{~mm}\end{array}$ & $\begin{array}{l}\mathrm{h} \leq 0,2 \mathrm{~s}, \max 2 \mathrm{~mm} \\
\mathrm{l} \leq \mathrm{s}, \max 25 \mathrm{~mm}\end{array}$ & $\begin{array}{c}\mathrm{h}=2,6 \mathrm{~mm} \\
\mathrm{I}=7,8 \mathrm{~mm}\end{array}$ & C \\
\hline \multirow[t]{2}{*}{7.} & \multirow{2}{*}{$\begin{array}{l}\text { Skupisko } \\
\text { porowatości }\end{array}$} & 2013 & $\begin{array}{l}\text { a) Maksymalny } \\
\text { wymiar sumy po- } \\
\text { wierzchni rzutowa- } \\
\text { nia niezgodności } \\
\text { spawalniczych } \\
\text { (włączając niezgod- } \\
\text { ności spawalnicze } \\
\text { systematyczne) } \\
\leq 16 \%\end{array}$ & $\begin{array}{l}\text { a) Maksymalny } \\
\text { wymiar sumy po- } \\
\text { wierzchni rzutowa- } \\
\text { nia niezgodności } \\
\text { spawalniczych } \\
\text { (włączając niezgod- } \\
\text { ności spawalnicze } \\
\text { systematyczne) } \\
\leq 8 \%\end{array}$ & $\begin{array}{l}\text { a) Maksymalny } \\
\text { wymiar sumy po- } \\
\text { wierzchni rzutowa- } \\
\text { nia niezgodności } \\
\text { spawalniczych } \\
\text { (włączając niezgod- } \\
\text { ności spawalnicze } \\
\text { systematyczne) } \\
\leq 4 \%\end{array}$ & $15,73 \%$ & $\mathrm{D}$ \\
\hline & & 2013 & $\begin{array}{l}\text { b) Maksymalny wy- } \\
\text { miar pojedynczego } \\
\text { pęcherza dla spoin } \\
\text { czołowych: } \\
\mathrm{d} \leq 0,4 \mathrm{~s} \\
\text { ale max } 4 \mathrm{~mm}\end{array}$ & $\begin{array}{l}\text { b) Maksymalny wy- } \\
\text { miar pojedynczego } \\
\text { pęcherza dla spoin } \\
\text { czołowych: } \\
d \leq 0,3 \mathrm{~s} \text {, } \\
\text { ale max } 3 \mathrm{~mm}\end{array}$ & $\begin{array}{l}\text { b) Maksymalny wy- } \\
\text { miar pojedynczego } \\
\text { pęcherza dla spoin } \\
\text { czołowych: } \\
d \leq 0,2 \mathrm{~s} \\
\text { ale max } 2 \mathrm{~mm}\end{array}$ & $\mathrm{~d}=2,2 \mathrm{~mm}$ & C \\
\hline \multirow[b]{2}{*}{8.} & \multirow[b]{2}{*}{ Pęcherz } & 2011 & $\begin{array}{l}\text { a2) w odniesieniu } \\
\text { do pola przełomu } \\
\leq 2,5 \%\end{array}$ & $\begin{array}{l}\text { a2) w odniesieniu } \\
\text { do pola przełomu } \\
\leq 1,5 \%\end{array}$ & $\begin{array}{l}\text { a2) w odniesieniu } \\
\text { do pola przełomu } \\
\leq 1 \%\end{array}$ & $0,58 \%$ & B \\
\hline & & 2011 & $\begin{array}{l}\text { b) Maksymalny wy- } \\
\text { miar pojedynczego } \\
\text { pęcherza dla spoin } \\
\text { czołowych: } \\
\mathrm{d} \leq 0,4 \mathrm{~s} \\
\text { ale } \max 5 \mathrm{~mm}\end{array}$ & $\begin{array}{l}\text { b) Maksymalny wy- } \\
\text { miar pojedynczego } \\
\text { pęcherza dla spoin } \\
\text { czołowych: } \\
d \leq 0,3 \mathrm{~s} \\
\text { ale } \max 4 \mathrm{~mm}\end{array}$ & $\begin{array}{l}\text { b) Maksymalny wy- } \\
\text { miar pojedynczego } \\
\text { pęcherza dla spoin } \\
\text { czołowych: } \\
\text { d } \leq 0,2 \mathrm{~s} \\
\text { ale } \max 3 \mathrm{~mm}\end{array}$ & $\mathrm{~d}=2,3 \mathrm{~mm}$ & B \\
\hline \multicolumn{7}{|c|}{ Poziom jakości złącza } & NSD \\
\hline
\end{tabular}




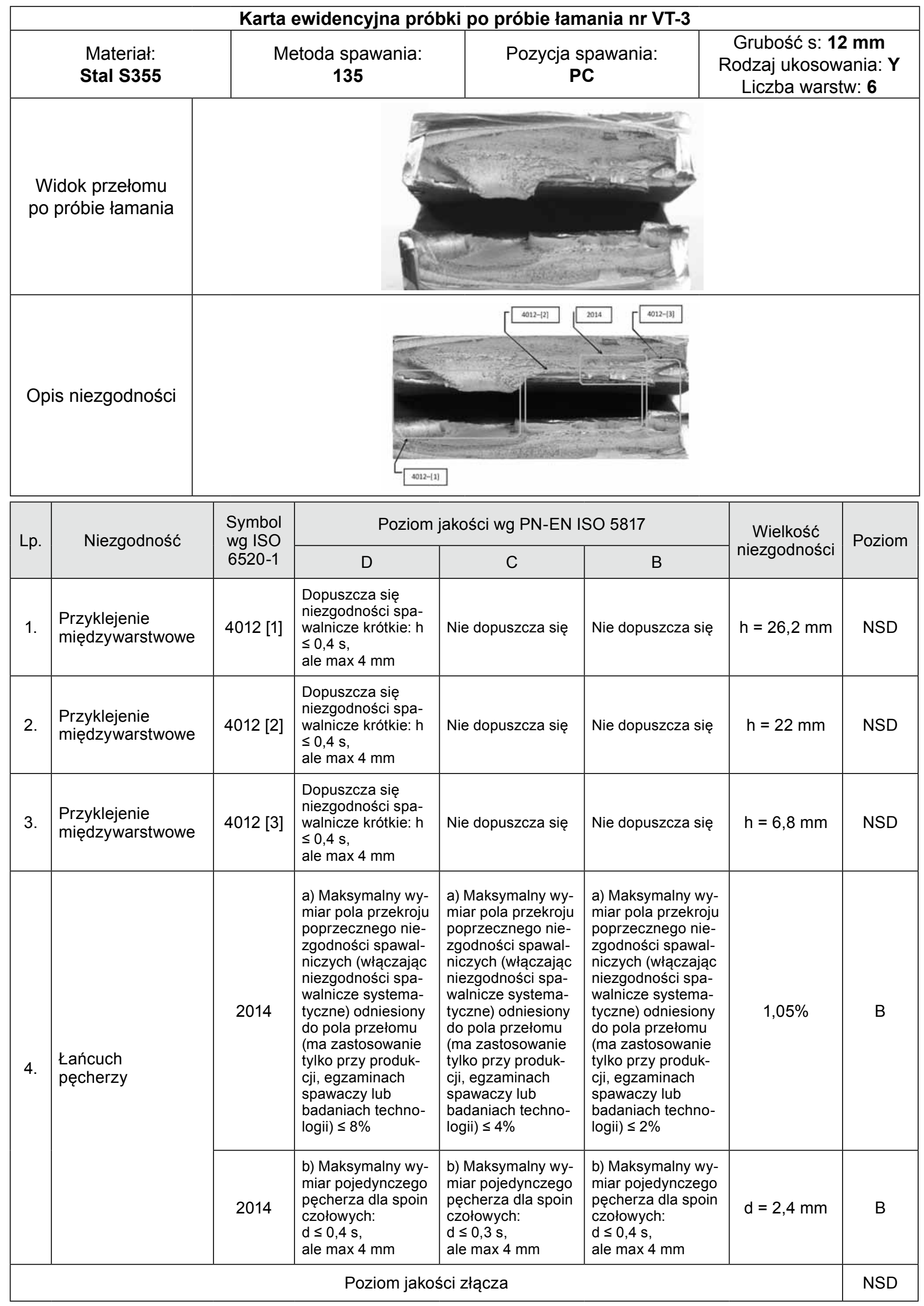









\section{Podsumowanie}

Próba łamania pozwala w przypadku spoin czołowych odkryć takie niezgodności, jak:

- przyklejenie międzywarstwowe i brzegowe (brak wtopienia),

- pęcherz gazowy (gniazda pęcherzy, pęcherze równomiernie rozłożone, łańcuch pęcherzy, pęcherz podłużny, pęcherz kanalikowy),

- wtrącenia żużla (liniowe, odosobnione, gniazda),

- wtrącenia metaliczne.

Przyklejenia międzywarstwowe mogą mieć różną postać - od dobrze widocznego przyklejenia, które podczas próby łamania zostało „otwarte” (widoczne, rozchylające się warstwy, tzw. „kaczy dzióbek”), aż do trudnego do zobaczenia uskoku pomiędzy warstwami (tzw. „balkonik”). Znacznie łatwiej rozpoznawalne są pęcherze. Pęcherz powstaje w wyniku uwięzienia w krystalizującej spoinie gazu - dlatego jego powierzchnia jest gładka i przez to błyszcząca. Bardzo często występuje sytuacja, kiedy widoczny na przełomie łańcuch pęcherzy przechodzi w przyklejenie międzywarstwowe - linia przyklejenia jest wówczas widoczna w dnie łańcucha pęcherzy. Wtrącenia żużla występują stosunkowo rzadko i są dobrze rozpoznawalne - czarne i matowe. Również wtrącenia metaliczne występują stosunkowo rzadko i są dobrze rozpoznawalne.

W przypadku spoin pachwinowych istotne jest wtopienie $\mathrm{w}$ środnik próbki. Próba łamania spoin pachwinowych pozwala na szybkie i łatwe stwierdzenie uzyskania wtopienia lub jego brak. W przypadku braku wtopienia krawędź blachy jest bez zmian i wygląda jak po obróbce mechanicznej przy przygotowaniu próbki przed spawaniem. W sytuacji, kiedy uzyskano wtopienie jest ono dobrze widoczne w postaci wyraźnego pasa przełomu (przy spawaniu w pozycji PA i PB) lub łuskowatych wtopień tzw. „falbanek" przy spawaniu w pozycji PF. Przy spawaniu w tej pozycji często może wystąić brak wtopienia na całej długości próbki. Wówczas na przełomie widoczne są odcinki, gdzie krawędź blachy ma postać po obróbce mechanicznej i odcinki, gdzie występuje wtopienie o łuskowatej postaci.

\section{Literatura}

[1] PM-EN 287-1:2011 Egzamin kwalifikacyjny spawaczy. Spawanie. Część 1: Stale.

[2] PN-EN ISO 5817:2009 Spawanie. Złącza spawane ze stali, niklu, tytanu i ich stopów (z wyjątkiem spawanych wiązką). Poziomy jakości według niezgodności spawalniczych.

[3] PN-EN ISO 6520:2009 Spawanie i procesy pokrewne. Klasyfikacja niezgodności spawalniczych w metalach. Część1: Spawanie.

[4] PN-EN 1320:1999 - Spawalnictwo. Badania niszczące spawanych złączy metali. Próba łamania.

[5] Praca zbiorowa: Encyklopedia techniczna. Budowa maszyn. Warszawa, WNT 1968.

[6] Antosiak J., Chodnikiewicz K., Golatowski T., Koselarz J., Nagel W., Soćko D., Stępniak R., Szulczyński J., Świerczyński J.: Prasy mechaniczne. Warszwa, WNT 1971.

[7] Bosiacki K., Marciniak Z., Seyna F.: Zarys tłocznictwa. Warszawa, PWT 1955.

[8] PN-EN ISO 17637:2011 Badania nieniszczące złączy spawanych. Badania wizualne złączy spawanych.

[9] PN-EN ISO 10042:2008 Spawanie. Złącza spawane w aluminium i jego stopach. Poziomy jakości dla niezgodności spawalniczych.

[10] Pakosz M.: Ocena przełomów złączy spawanych na podstawie próby łamania - analiza przypadków. Praca dyplomowa magisterska (promotor dr hab. inż. J. Słania prof. P.Cz), Politechnika Częstochowska 2012.

\section{Miesięczne i roczne spisy treści oraz streszczenia artykułów opublikowanych w Przeglądzie Spawalnictwa są dostępne na stronie internetowej:}

$$
\text { wWw.pspaw.ps.pl }
$$

